\title{
IMPLEMENTASI AKAD AL-MUSAWAMAH \\ PADA PASAR TRADISIONAL
}

Oleh: Rachmad Rizqy K, Ph.D.

Arviansyah

\begin{abstract}
Abstrack
We will meet daily transaction contracts in traditional markets between the seller (al-Bai') and the buyer (al-Musytarl) to avoid the usury contract with a bargaining agreement (Musawamah) which is arranged between the seller and the buyer, with the principal profit stated by the seller at the end of the day. buyers (Murobahah) so that transactions carried out by both parties are securely established, which of course is widely applied in traditional and modern markets and can even be found in the Online Shop or Marketplace
\end{abstract}

Keywords : al-Bai; al-Musytarl, Murobahah

\begin{abstract}
Abstrak
Akad transaksi sehari hari dipasar tradisional akan kita temui antara penjual (al-Bai') dan pembeli (al-Musytarl) untuk menghindari dari akad ribawi dengan kesepakatan tawar menawar (Musawamah) yang diatur antara penjual dan pembeli, dengan keuntungan pokok yang diutarakan penjual pada pembeli (Murobahah) sehingga, Transaksi yang dilakukan kedua belah pihak terjalin secara aman, yang tentunya banyak diterapkan di pasar-pasar tradisional maupun modern bahkan juga bisa ditemui di Online Shop atau Marketplace..
\end{abstract}

Kata Kunci : al-Bai; al-Musytarl, Murobahah.

\section{Pendahuluan}

Akad Al-Musawamah merupakan akad transaksi yang sering dijumpai antara pedagang dan pembeli di pasar tradisional bahkan modern, pada setiap toko atau lapak penjual yang menjual kebutuhan pokok maupun kebutuhan sehari-hari

Dimana dengan akad ini mempermudah terjadinya deal saat terjadi negosiasi antara penjual dan pembeli, dimana akhir atau titik temu dalam seriap transaksi tawar menawar adalah kesepakatam antara kedua belah pihak yang masing-masing dari pihak telah menyetujui hasil tersebut seperti nominal uang yang harus dibayar atas barang atau jasa tersebut

Tentunya disini kita akan membahas mengenai spesifik atau berfokus pada Akad jual beli AlMusawamah, yang merupakan jual beli dengan sistem tawar menawar yang sering kita jumpai antara penjual dan pembeli dalam menyepakati suat harga yang menjadi inti dari transaksi tawar menawar

\section{Hukum ekonomi syariah}

Sekolah Tinggi Islam SEBI 2021 
tersebut, Dimana transaksi ini juga disebut transaksi biasa karena, sudah lumrah kita temui terjadinya tawar menawar antara penjual dan pembeli disetiap toko-toko atau gerai-gerai yang ada dipasar atau pun tempet-tempet lain.

\section{Rumusan Masalah}

Dikutip dari Republika.co.id

Pemerintah melalui Bursa Efek Indonesia (BEI) memastikan instrumen pasar modal syariah halal dan tidak bertentangan dengan ajaran Islam. Irwan Abdalloh, kepala departemen pengembangan pasar BEI, mengatakan: "Setiap layanan yang diberikan dalam pelaksanaan transaksi efek adalah adil dan tidak akan mengambil tindakan yang tidak sesuai dengan prinsip-prinsip hukum Syariah (ada 14 transaksi yang dilarang)," Di Seminar Jurnalis Pasar Modal Syariah di Pekanbaru, Jumat.

Menurut Ilwan, pasar modal syariah menggunakan mekanisme tawar menawar yang berkelanjutan dari akad "Bai al musawamah" dan karenanya adil. Beberapa aturan Syariah juga berlaku, seperti akad jual beli (Ba'i), surat berharga yang diperdagangkan adalah saham yang sesuai dengan hukum Syariah, dan pembeli dapat menjual surat berharga menurut prinsip Qabdh Hukmi setelah transaksi.

Selain itu, ia juga menyatakan bahwa sejak 2010, BEI terus mengembangkan investasi syariah di pasar modal. Ia melanjutkan, untuk mengurangi tingkat berlebihan atau ambiguitas dalam berinvestasi di saham syariah, BEI mengajukan surat keputusan pasar modal syariah yang telah disetujui oleh MUI. BEI juga mengeluarkan Surat Keputusan No. 1. Pada tanggal 8 Maret 2011, Dewan Nasional Hukum Islam Majelis Ulima Indonesia (DSN-MUI) menyetujui Keputusan No. 80 tentang Penerapan Prinsip Syariah Dalam Mekanisme Perdagangan Pasar Reguler Surat Berharga di Bursa Efek.

Gunawan Yasni, anggota Komisi Nasional Hukum Syariah, mengatakan pengesahan fatwa tersebut memberikan landasan atau hukum keuangan yang kuat bagi operasi perdagangan di BEI. Mekanisme lelang berkelanjutan yang digunakan BEI dalam transaksi efek ekuitas pasar reguler telah sesuai dengan prinsip-prinsip hukum Syariah.

“Oleh karena itu, pemerintah berharap agar masyarakat tanpa ragu-ragu berinvestasi syariah di pasar modal, yang pada gilirannya akan meningkatkan jumlah investor domestik di pasar modal Indonesia," ujarnya. "Bagi investor pasar modal yang ingin menghindari riba dan sistem yang lebih adil, pasar modal syariah adalah pilihan lain," lanjut Gunawan ${ }^{1}$. Oleh karena itu, dapat disimpulkan bahwa ruang lingkup transaksi akad Al-Musawamah sebenarnya sangat luas, tidak hanya dalam bidang transaksi tawar menawar antara pembeli dan penjual di pasar atau toko, tetapi juga perangkat atau bidang lainnya yang tentunya mempunyai cakupan yang sangat luas dengan bidang-bidangnya tersendiri yang belum kita ketahui atau kita pelajari namun, akan dapat kita jumpai atau bahkan lakukan kelak nanti saat pada masanya karena tentunya tugas kita sebagai seorang muslim adalah memajukan islam ini sendiri dari berbagai bidang seperti bidang ekonomi ini, karena islam pernah berjaya sebelumnya pada segala bidang pada masa dahulu, itulah tugas kita sebagai muslim yang harus faham dalam segala bidang dan sektornya supaya islam bisa kembali berjaya.

Kita bisa contoh bagaimana islam dimasa dahulu bisa berjaya dari para sahabat bahkan langsung dari Rasulullah SAW, saat bertransaksi maka contoh kecil yang dapat kita ambil adalah dimana saat transaksi jual beli yang baik dan dibolehkan dalam islam ini sperti akad musawamah ini. Dimana akad ini merupakan akad yang dibolehkan dalam islam karena tentunya ada keridhoan dan keikhlasan didalamnya yang merupakan kunci penting dimana agar kita terhindar dari jual beli yang dilarang agama atau gharar bahkan riba yang ada didalamnya yang sudah jelas haram hukumnya dan dilarang oleh agama kita yakni islam.

\footnotetext{
${ }^{1}$ https://www.republika.co.id/berita/II4vjt/pasar-modal-syariah-dipastikan-halal 2 | Hukum ekonomi syariah Sekolah Tinggi Islam SEBI 2021
} 


\section{Tujuan Masalah}

Untuk mengetahui bagaimana penerapan akad al-musawamah ini dilakukan dipasar tradisional dan bagaimana keadaan pasar tradisional itu dimasa kini dengan perbandingan sistem transaksi sekarang..

\section{Pengertian Akad}

Akad berasal dari kata al-'Aqd yang merupakan bentuk masdar dari kata 'Aqada dan jamaknya adalah al-'Uqud yang artinya perjanjian (yang tercatat) atau kontrak. Menurut Ensiklopedi Hukum Islam, kata al-'aqd artinya perikatan, perjanjian, dan permufakatan (al-ittifaq).

Akad tidak lepas dari pembahasan fikih muamalah. Allah SWT telah memerintahkan hamba-Nya untuk memenuhi akad sebagaimana termaktub dalam QS. Al Maidah ayat 1 sebagai berikut:

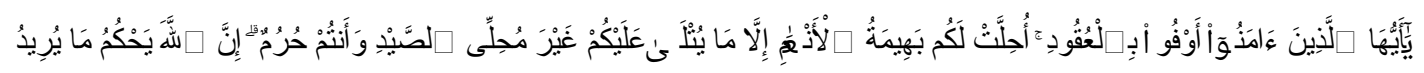

Artinya: "Hai orang-orang yang beriman, penuhilah akad-akad itu. Dihalalkan bagimu binatang ternak, kecuali yang akan dibacakan kepadamu. (Yang demikian itu) dengan tidak menghalalkan berburu ketika kamu sedang mengerjakan haji. Sesungguhnya Allah menetapkan hukum-hukum menurut yang dikehendaki-Nya." (QS. Al Maidah: 1).

Para fuqaha mendefinisikan akad sebagai perikatan antara ijab dan qabul yang dibenarkan syara', yang menetapkan persetujuan kedua belah pihak. Ijab merupakan permulaan penjelasan yang keluar dari salah seorang yang berakad. Sedangkan, qabul adalah jawaban dari pihak lain (pihak kedua) setelah adanya ijab. ${ }^{2}$

Namun tentunya akad yang akan dibahas lebih dalam yakni akad al-musawamah yang mana akad ini terjadi saat transaksi jual beli antara penjual dan pembel, dimana jual merupakan kesepakatan antara dua pihak secara sukarela untuk menukarkan barang atau barang berharga, dimana satu pihak menerima barang tersebut, dan pihak lainnya menerima barang tersebut menurut kesepakatan atau kondisi yang wajar dan disepakati. Ini dapat mencakup konsep barang dan uang, dan sifat benda itu harus dievaluasi, yaitu suatu benda yang berharga dan dapat dibuktikan menurut syara, Selama syariat tidak melarang penggunaan harta, penggunaan harta yang diboleh meliputi transaksi jual beli tersebut.

\footnotetext{
${ }^{2}$ https://news.detik.com/berita/d-5615394/arti-akad-menurut-bahasa-dalam-hukum-islam

3 Hukum ekonomi syariah

Sekolah Tinggi IsIam SEBI 2021
} 


\section{Rukun Akad}

Dalam fikih muamalah dijelaskan bahwa rukun adalah salah satu unsur yang membentuk terjadinya akad. Dikutip dari buku Pendidikan Agama Islam Fikih untuk MA kelas X oleh Djedjen Zainuddin, rukun akad terdiri dari 5 hal.

1. Aqid

Aqid yaitu orang yang melakukan akad. Seorang akid haruslah memenuhi keempat syarat yang telah ditetapkan, di antaranya balig, berakal, kedua belah pihak cakap berbuat, dan atas kehendaknya (tidak dipaksa).

2. Benda yang menjadi objek akad.

Objek akad harus nyata. Benda tersebut juga bukanlah benda terlarang oleh syara' dan bukan milik pihak lain.

3. Tujuan dan maksud pokok akad

Dalam akad, harus ada tujuan dan maksud yang jelas. Apakah akad tersebut untuk jual beli, hibah, atau yang lainnya.

\section{Ijab}

5. Qabul

Dalam ijab dan qabul ada beberapa syarat yang harus dipenuhi. Di antaranya harus terang pengertiannya menurut 'urf (kebiasaan), harus sesuai antara ijab dan qabul, dan memperhatikan kesungguhan dari pihak-pihak yang bersangkutan (tidak ragu-ragu) ${ }^{3}$.

Adapun, jumhur ulama berpendapat bahwa rukun akad mencakup tiga hal, yaitu Al-'Aqidain (pihakpihak yang berakad), Ma'qud 'Alaih (objek akad), dan Sighat al-'Aqd (pernyataan untuk mengikatkan diri).

\section{Pengertian Akad Al-Musawamah}

Bai Al-Musawamah atau akad musawamah merupakan akad jual beli dimana penjual tidak memberitahukan harga pokok dan keuntungan yang didapatnya dari sebuah produk atau sejenisnya dimana haraga ditentukan melalui proses tawar menawar antara penjual dan pembeli dengan kesepakatan antara kedua belah pihak tersebut dengan saling ikhlas dan ridho atas kesepakatan yang sebelumnya kedua belah pihak itu sepakati.

\footnotetext{
${ }^{3}$ https://news.detik.com/berita/d-5615394/arti-akad-menurut-bahasa-dalam-hukum-islam

4 Hukum ekonomi syariah

Sekolah Tinggi IsIam SEBI 2021
} 
Tentunya hukum jual beli dengan akad ini dibolehkan dalam islam karena inti dari akad ini merupakan keikhlasan antara keduan belah pihak lewat harga yang sudah ditentukan lewat proses tawar menawar tersebut walaupun, penjual tidak memberitahuan harga pokok atau keuntungan yang diperolehnya namun kembali lagi dimana jual beli ini dihasilkan dari keikhlasan dan keridhoan kedua belah pihak tersebut, Dan tentunya karena akad ini merupakan akad yang seing terjadi atau digunakan saat seseorang akan membeli suatu barang disebuah toko atau bahkan pasar pastinya akad inilah yang sehari-hari kita gunakan.

Karena agar transaksi yang kita lakukan merupakan transaksi jual beli yang benar dan dobolehkan dalam agama kita yakni islam, Dimana harus pula diperhatiakan oleh setiap penjual maupun pembeli saat bertransaksi jual beli jangan sampai ada unsur tipu-menipu atau hal yang dapat merugikan salah satu pihak dalam transaksi, karena tentunya dapat menimbulkan rusaknya jual beli tersebut bahkan dapat juga menimbulkan dosa pada penjual atau pembeli, atau bahkan keduanya.

Allah SWT berfirman ${ }^{4}$

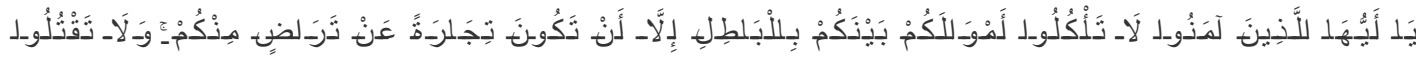

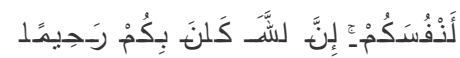

Artnya : Wahai orang-orang yang beriman, janganlah kamu memakan harta sesamamu dengan cara yang batil(tidak benar), kecuali berupa perniagaan atas dasar suka sama suka diantara kamu. Janganlah kamu membunuh dirimu, sesungguhnya Allah adalah Maha Penyayang kepadamu. (Q.S. An-Nissa:29)

Surat an-nisa ayat 29 tersebut merupakan larangan tegas mengenai memakan harta orang lain atau hartanya sendiri dengan jalan batil, memakan harta sendiri dengan jalan batil adalah membelanjakan hartanya pada jalan maksiat. memakan harta orang lain dengan cara batil ada berbagai caranya seperti pendapat Suddi, yaitu memakainya dengan jalan riba, judi, menipu, menganiaya. termasuk juga dalam jalan yang batal ini segala jual beli yang dilarang syara (Syekh H. Abdul Halim Hasan Binjai, 2006: 258)

Wahbah Az Zuhaili menafsirkan Ayat tersebut dengan kalimat janganlah kalian ambil harta orang lain dengan cara haram dalam jual-beli (Jangan pula) dengan riba, judi, merampas dan penipuan. akan tetapi dibolehkan bagi kalian untuk mengambil harta milik selainmu dengan cara dagang yang lahir dari keridhoan dan keikhlasan hati antara 2 pihak dan dalam koridor syar'I. Dengan tijarah adalah usaha memperoleh untung lewat jual beli tak saling rela adalah kesepakatan yang sama-sama muncul antara kedua pihak penjual dan pembeli tanpa ada unsur penipuan. ${ }^{5}$

\section{Metode Penelitian}

Metode yang digunakan dalam penelitian ini merupakan metode dengan mencari sumber-sumber terpercaya dari situs web di internet menggabungkan sumber-sumber tersebut menjadi satu topik yang berkesinambungan yang tersusun dan terperinci

\footnotetext{
${ }^{4}$ https://tafsiralquran.id/tafsir-surah-an-nisa-ayat-29-prinsip-jual-beli-dalam-islam/

5 Hukum ekonomi syariah

Sekolah Tinggi Islam SEBI 2021
} 
mengenai hasil informasi-informasi yang didapatkan dari berbagai sumber tersebut mengenai akad al-musawa mah dan beberapa yang terkait mengenai informasi akad al-musawa mah juga dibarengi dengan fakta yang merupakan hasil dari lapangan atau pengalaman yang dialami saat berkunjung ke pasar tradisional yang menjadi gudangnya transaksi jual-beli akad al-musawa mah tersebut.

Penelitian tersebut bertujuan supaya atau informasi yang disajikan merupakan informasi yang riil berdasarkan sumber-sumber terpercaya dan hasil dari praktek terjun langsung dari lapangan yang tentunya menjadi Nilai plus dalam penulisan ini berdasarkan fakta yang ada yang dialami penulis supaya data yang disajikan sesuai dengan fakta dan keadaan yang ada atau yang sebenar-benarnya

Dan penggunaan pendekatan metode tersebut karena yang ditelaah dalam penelitian ini berfokus pada tema mengimplementasikan akad al-musawa mah di pasar tradisional yang tentunya menghadirkan fakta-fakta dari hasil observasi yang telah dilakukan di pasar tradisional lebih spesifiknya di pasar modern tradisional Cicalengka Kabupaten Bandung Jawa Barat yang merupakan salah satu pasar yang menjadi tujuan penjual dan pembeli daerah-daerah luar Cicalengka bahkan dari luar Bandung yang tentunya memudahkan penulis dalam menemukan atau mengemukakan fakta yang ada berdasarkan fakta dan informasi yang dapat dipercayai.

\section{Melihat Cara Rasulullah Bertransaksi Jual Beli;}

"Sebagai pedagang, Rasulullah SAW sangat amanah, jujur, profesional, namun gigih dan memiliki wirausaha yang tinggi dalam menjalankan kegiatan usahanya," ${ }^{6}$ untuk meneladani cara berdagang Rasulullah dapat dilakukan dengan beberapa cara. Pertama, para pedagang diminta bisa tertib mutu dalam memenuhi standar yang dipersyaratkan, sering kali pedagang menjual dagangan yang tidak sesuai dengan keinginan konsumen. "Di sini, pedagang harus bertanggung jawab untuk menjual buah, barang, dan jasa yang sesuai dengan harapan masyarakat luas.

secara etika bisnis, para pedagang juga harus dapat membangun kepercayaan dan kelanggengan usahanya. Caranya dengan mengikuti aturan yang tidak menipu antarpedagang maupun konsumen.

Seperti saat transaksi yang dilakukan oleh Nabi Muhammad SAW, Beliau saat berinteraksi dengan konsumen, beliau menyebutkan harga asli dari barang yang diberniagakannya dan menyerahkann sepenuhnya kepada pembeli atau orang tersebut untuk memberi harga lebih dari barang tersebut atau bisa disebut dengan akad murabahah, dari situlah keuntungan yang didapatkan beliau jauh berkali lipat banyaknya dari pedagang lainnya. Beliau sangat jujur hingga kemudian beliau semakin dipercaya oleh orang orang, yang membuatnya semakin sukses dan disenangi setiap orang, disitulah seharusnya setiap menjual harus dapat mengimplementasikan tata cara berniaga Nabi Muhammad SAW.

Namun tentunya cukup sulit mengimplementasikan cara tersebut dipasar tradisional pada masa ini, karena dapat menjadi sebuah masalah baru untuk pedagang-pedagang lain, tentu semua itu akan dianggap sangat merugikan bagi setiap pesaingnya atau pedagang lain, karena jika tentu sistem tata cara berniaga Nabi Muhammad SAW, diadopsi oleh satu saja penjual yang ada dipasar tradisional tersebut maka, sudah pastilah pedagang tersebut akan menjadi bahan serbuan dari pelanggannya karena, memaparkar harga sebenarnya dari produk yang diinginkannya, disisi lain membuat pesaing atau pedagang lainnya menjadi sepi jika barang yang dijualnya sama dengan pedagang yang menerapkan sistem perdagangan Rasul tadi, Bisa jadi pedagang tersebut menjadi sasaran kebencian dari pedagang lainnya, karena cara berdagangnya yang begitu sangat transparan tentunya mungkin sangat merugikan pedagang lain, walau sebenarnya untuk rezeki setiap orang telah ALLAH SWT tentukan dan tidak akan tertukar dengan orang lain.

\footnotetext{
${ }^{6}$ https://www.republika.co.id/berita/q3c7og366/cara-berdagang-rasulullah

6 | Hukum ekonomi syariah

Sekolah Tinggi IsIam SEBI 2021
} 
ALLAH Berfirman yang artinya:

"Barangsiapa bertakwa kepada Allah niscaya Dia akan membukakan jalan keluar baginya, dan Dia memberinya rezeki dari arah yang tidak disangka-sangkanya. Dan barang siapa bertawakal kepada Allah, niscaya Allah akan mencukupkan (keperluan)nya." (QS ath-Thalaq: 2-3).

Mungkin cukup sulit untuk penjual atau pedagang dipasar tradisional untuk menerapkan sistem jual beli Rasulullah, Karena tentunya banyak faktor yang menjadi penghalang dan penghambat tentunya dalam berniaga atau bertransaksi sesuai cara rasul, Kebanyakan pelanggan pada akhirnya dipasar tradisional menerapkan sistem jual beli dengan langsung menetapkan harga yang cukup tinggi dari harga barang yang dibelinya sebelumnya dari produsen atau pihak distributor.

Penjual atau pedagang menetapkan harga jual dari barang yangyang mereka jual $2 \mathrm{X}$ lipat dari harga aslinya, tentunya semua itu dilakaukan karena merupakan salah satu strategi untuk menghadapi konsumen yang sudah pastinya akanproses tawar menawar habis habisan barang yang diinginkannya yang merupakan akad musawamah, karena mereka tau harga yang ditawarkan penjual kepada mereka bahwasannya merupakan bukan harga final yang langsung diteteapkan oleh pihak penjual, melainkan harga yang masih bisa diotak atik atau masih bisa ditawar menawar oleh mereka sampai proses tawar menawar tersebut menuju hasil akhir harga yang disepakati oleh kedua belah pihak, yakni penjual dan pembeli, tentunya sipenjual pun tidak boleh mengambil untung yang berlipat ganda pada transaksi jual beli tersebut. Walaupun pada akad musawamah ini penjuak tidak mengapa jika tidak menyebutkan harga pokok beserta jeuntungan yang didapatnya, Namun sekali lagi penjual tidak boleh mematok atau mengambil untuk yang sangat besar, boleh menawarkan dengan harga yang cukup tinngi, tapi harga tersebut tentunya merupakan harga yang masih dapat dinegosiasi oleh kedua belah pihak, janagan sampai membuat salah satu pihak dirugikan oleh transaksi tersebut.

Namun umumnya untuk barang yang diperjual belikan dipasar tradisional tersebut yang dimana pihak penjual menawarkan haraga kepada konsumen dengan harga yang masih bisa dinego, merupakan barang-barang atau benda benda mata, seperti pakaian, perabotan dan lain sebagainya.

Untuk pedagang yang menjual kebutuhan pangan, seperti makanan pokok, makanan ringan, sayur mayur dan lainnya, Akad Musawamah ini sangat jarang ditemukan karena pihak penjual sudah mematok harga mati untuk barang yang mereka jual tersebut tentunya dengan keuntungan yang sudah termasuk didalamnya. Walaupun kadang dapat kita jumpai pedagang yang dimana barang dagangannya dapat kita tawar, namun pastinya potongan atau selisih harga yang mereka berikan akan sangat keci, tidak akan berbeda jauh dari pesingnnya atau pedagang lain yang menjual komoditi atau barang dagangan yang sama. Karena untuk harga makanan sendiri baik makanan pokok, sayuran, buah buahan, untuk harag sudah pasti setiap tokonya dipasar tradisional akan sama, karena akan berpengaruh dari hasil panen atau kelangkaan stok dari bahan makanan tersebut, yang menyebabkan serentak harga bahan makanan tersebut sama.

\section{HARGA YANG TETAPKAN SETIAP TOKONYA}

Dari hasil pengalaman dipasar tradisional mengenai Akad Al-Musawamah, Pedagang disetiap toko-tokonya masing, masing menetapkan harga yanag tidak jauh berbeda dengan toko-toko lainnya atau pesaingnya di daerah pasar tradisional tersebut, karena jikalau ada yang mematok harga yang jauh berbeda untuk barang yang sama dengan toko lainnya makan pedagang tersebut sudah pasti merauk keuntungan yang jauh lebih besar dari toko lainnya, atau juga merupakan strategi dagang mereka di mana saat proses tawar menawar atau saat Akad Al-Musawamah ini terjadi, pelanggan berasumsi bahwa toko yang menawarkan barang tersebut lebih murah karena saat ditawar oleh konsumennya, sang pemilik toko memberikan harga yang jauh turun berbeda dari harga awal yang ditawarkan sang pemilik toko tersebut kepada konsumennya, untuk itu si konsumen akan terpengaruh dengan cara tersebut karena dia yakin bahwa toko tersebut memiliki keunggulan dari toko yang lainnya didaerah pasar tersebut. 
Proses diatas atau Akad diatas merupakan sesuatu yang sah dan tidak haram karena disini merupakan Akad Al-Musawamah dimana kedua belah pihak telah menyetujui kesepakatan dari harga barang tersebut dan si pedagang pun sah sah saja tidak menyebutkan harga asli dan keuntungan yang diambilnya dari barang tersebut, Untuk itulah Akad Al-Musawamah merupakan akad atau aturan jualan beli yang merupakan aturan jual beli dalam islam yang mengatur hukumnya tawar menawar tersebut antara kedua belah pihak penjual dan pembeli agar kedua belah pihak nyaman, si pedagang senang dengan keuntungan halal yang didapatkannya dan si pembeli pun sedang dan ridho dengan harga tersebut dan sekaligus senang dengan barang yang telah dibelinya dari toko atau pedagang tersebut.

Namun tentunya setiap toko-toko yang ada dipasar tradisional tersebut dalam menawarkan harga atau menetapkan harga barang yang di jualnya dalam setiap kali transaksi jangan sampai mengatakan sesuatu yang berujung dusta, misalkan saat proses tawar menawar antara penjual dan pembeli tersebut, si penjual jangan sampai mengatakan bahwan keuntungan yang diambilnya sekian atau sedikit saja dari barang yang sedang melalui proses tawar menawar tersebut, sedangkan kenyataannya keuntungan yang penjual tersebut lebih dari cukup atau memang cukup besar dari barang yang ditawarkannya, karena setiap perkataan dusta akan berujung pada dosa, jangan sampai terbiasa melakukannya, karena dalam proses tawar menawar tersebut akhirnya jika terjadi deal dengan harga yang telah disepakati namun tentunya transaksi tersebut tentunya tidak sempurna karena dalam prosesnya ada dusta walaupun si pembeli ridho dan percaya akan perkataan tersebut namun, bagaimana jika pembeli tersebut tidak ridho?, tentunya si penjual bisa berkali lipat lagi dosa yang ia lakukan, apalagi jika dusta tersebut ia lakukan atau katakan setiap kali kepada konsumen atau pembeli yang menawar barangnya.

ALLAH SWT, Befirman:

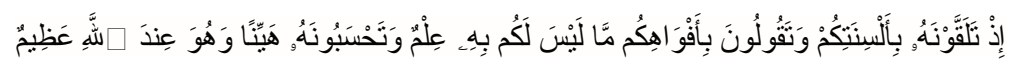

Artinya:(Ingatlah) di waktu kamu menerima berita bohong itu dari mulut ke mulut dan kamu katakan dengan mulutmu apa yang tidak kamu ketahui sedikit juga, dan kamu menganggapnya suatu yang ringan saja. Padahal dia pada sisi Allah adalah besar.(QS An-Nur : 15)

Untuk itu akan setiap berhati hati kepada konsumennya, jangan sampai berkata yang bukan sebenarnya karena jika terus dilakukan kegiatan tersebut, tentunya akan menjadi sebuah kebiasaan yang sangat sulit dihilangkan, jangan sampai setiap pedagang menghalalkan segara cara demi menarik minat pembeli untuk membeli barang yang ada ditokonya tersebut.

Berdasarkan hasil pengalaman sering dijumpai bahwa seorang pedagang berkata kepada pembelinya bahwa keuntungan yang didapat dari barang yang dijual tersebut sangat kecil, atau bahkan jika si pembelil menawar dengan harga yang sangat murah dari awal harga yang telah ditawarkan penjual si penjual atau pemilik toko tersebut berkata bahwa tidak ada keuntungan yang ia dapatkan bila harganya sekian seperti yang ditawarkan oleh pembelinya, tentunya kita tidak tahu bahwa penjual berkata dengan sejujur-jujurnya atau bahkan dusta namun tentunya kejadian seperti ini sangat sering kita alami atau jumpai saat kita berkunjung ke sebuah toko dipasar tradisional saat mencari sebuah barang dan ingin menawar barang tersebut tentunya. dan lagi harus diperhatikan kepada setiap penjual untuk tidak berkata dusta berkatalah dengan sejujur-jujurnya mengenai barang yang ia jual Entah dari keadaan yang sesungguhnya dan juga harga yang wajar walaupun tidak disebutkan harga pokok dari barang tersebut. Dan ebagai pembeli pun harus diperhatikan karena dalam menawar barang tentu jangan sampai menawar dengan harga yang tidak masuk akal dari harga awal yang ditawarkan oleh penjualnya juga tidak boleh menawar barang yang dalam proses tawar-menawar oleh orang lain karena kegiatan tersebut merupakan kegiatan yang dilarang oleh Rasulullah SAW.

Jadi dapat disimpulkan bahwa setiap kegiatan jual beli atau tawar-menawar yang terjadi di setiap toko atau pasar pasar tradisional antara penjual dan pembeli ada etika dan aturan aturan yang harus ditaati entah itu dari aturan aturan pemerintah juga aturan dari Rasulullah Shallallahu Alaihi Wa Sallam Yang pastinya aturan tersebut merupakan aturan yang baik dan harus untuk diikuti, khususnya kepada kita selaku umatnya karena bisa kita lihat pada masa kekhalifahan Umar Bin Khattab beliau langsung turun ke pasar dan berkata. 


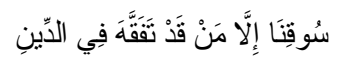

"Jangan berjualan di pasar ini para pedagang yang tidak mengerti dien (muamalat)".

Imam Malik juga riwayatkan bahwa Umar Bin Khattab memerintahkan penguasa untuk mengumpulkan semua pedagang dan pelaku pasar, kemudian menguji mereka satu per satu, dan menemukan bahwa sebagian dari mereka tidak memahami hukum jual beli. Ia melarang masuk pasar, sekaligus menyuruhnya belajar fiqh muamalat, jika ia mengerti, orang itu boleh masuk pasar. ${ }^{78}$

Di situ kita bisa lihat betapa tegasnya beliau kepada setiap pedagang atau bahkan setiap pelaku pasar yang tidak mengerti mengenai jual beli atau bahkan yang tidak mengikuti aturan Islam agar belajar terlebih ddahulu bagi mereka khususnya yang tidak memahami aturan muamalat atau transaksi perdagangan yang benar. tentunya apa yang beliau larang dan beliau lakukan merupakan pemahaman atau pengetahuan yang beliau amalkan dari Rasulullah yang harus kita lakukan dan kita taati juga sebagai umatnya yang mana perintah tersebut yang merupakan pedoman kita dalam setiap kegiatan kita entah dari kegiatan jual beli bahkan lebih banyak dan luas lagi.

\section{KEADAAN PASAR TRADISIONAL SEKARANG}

Tentunya tidak lengkap membahas akad musawamah ini tanpa melihat keadaan pasar tradisional sekarang yang menjadi bisa disebut pusat dari transaksi Akad Al-Musawamah ini, tentunya memang sebenarnya akad ini tidak hanya terjadi didalam pasar tradisional saja atau bahkan toko toko yang berada dijalanan sana, Namun transaksi Akad Al-Musawamah ini di zaman saat ini juga terjadi Transaksi digital seperti MARKETPLACE dan ONLINESHOP, Tentu tidak mengapa transaksi tersebut terjadi dan hukumnya sah-sah saja, namun disisi lain,unsur kecurangan bisa saja lebih besar terjadinya karenakedua belah pihak tidak saling bertemu secara tatap muka baik konsumen pembeli atau pun produsen penjual,jadi tentunya setiap pembeli harus lebih berhati-hati dengan transaksi tersebut karena transaksi tersebut hanya mengandalakan fitur chat saja, walaupun kadang ada pada MARKETPLACE, dimana si penjual berkomunikasi melalui videocall, namun tentunya itu sangat jarang kita temui. Walaupun ada yang berkomunikasi melalui videocall tadi tentunya masih banyak unsur kejahatan atau kecurangan yang dapat terjadi, seperti si penjual yang dapat berdusta tentunya mulai dari kualitas

barang dan jumlah harga yang sebenarnya dihargai atau bahkan jumlah barang yang sebenarnya berlimpah namun, sipenjual mengatakan barang tersebut stoknya terbatas atau langka, tentunya dari pada itu bisa kita lihat bahwa potensi dari jual beli atau transaksi secara online ini lebih berpotensi dalam terjadinya kecurangan, walaupun si pembeli sudah ridho dengan barang yang dibeli dan tawar menawar dari harga yang disepakati sebelumnya, namun tentunya barang tersebut belum hadir ditangan konseumen atau pembeli tersebut,

Umumnya pembeli akan tergiur oleh harga yang ditawarkan pada MARKETPLACE atau ONLINESHOP tersebut karena memang harga yang ditawarkan memang lebih murah dibanding tokotoko yang menjual di pasar tradisional tersebut kemudahan dimana barang yang dikirimkan pada konsumen atau pembeli tersebut, dimana para pembeli tidak perlu pergi ke luar memang sesuatu yang cukup menggiurkan.

Tapi mengapa harga yang ditawarkan pada MARKETPLACE atau ONLINESHOP lebih murah dibandingkan toko-toko online yang berada di pasar-pasar tradisional tersebut lebih murah?. Karena dimana mereka menjual barang yang dijualnya berasal langsung dari produsennya langsung atau bahkan pihak produsen ynag secara langsung membuka toko onlinenya, Tentunya berbanding dengan para penjual dipasar-pasar tradisional yang menjual barang, dimana barang yang mereka dapatkan tersebut sebelumnya mereka beli dari grosir-grosir dipusatnya, dimana grosir-grosir tersebut juga mendapat barang dari pihak produsen atau distributor yang mendistribusikan barangnya kepada pihak-

\footnotetext{
${ }^{7}$ https://www.republika.co.id/berita/qcq4ub430/umar-bin-khattab-usir-pedagang-yang-tak-paham-fiqihmuamalat 
pihak grosir tersebut yang ada dipusat-pusat tentunya, yang mana pastinya pihak grosir tersebut pastinya mematok harga yang lebih dari pihak produsen, karena di situlah keuntungan mereka dapatkan,

Akad Al-Musawamah juga dapat terjadi antara pihak grosir dengan produsen atau distributor namun tentunya dalam jumlah yang besar berbanding dengan pihak toko-toko dipasar tradisional yang menjual pada konsumen secara satuan atau eceran, pihak grosir dan distributor passtinya akan melakukan proses tawar menawar dengan kesepakatan jumlah barang yang besar tentunya seperti bisa perkodian atau juga sebagainya.

Jadi dari keadaan diatas tentunya pada pasar-pasar tradisional dimasa kini terjadi penurunan minat pembeli khususnya dibidang Fashion atau pakaian karena para pembeli atau konsumen lebih sering membeli barang berupa pakaian atau benda benda tersebut di onlineshop, memang keadaan seperti ini cukup meresahkan atau bahkan sangat berpengaruh pada pendapatan penjual-penjual yang ada pada toko-toko pada pasar tradisional tersebut, inovasi-inovasi harus dapat digagas oleh setiap penjual atau tokonya, dimana saingan atau kompetitor mereka bukan hanya toko sebelah atau toko-tpkp yang ada pada pasar tradisional tersebut, namun juga Marketplace dan Onlineshop yang menawarkan harga yang cukup menarik, untuk itu banyak juga dari para penjual dipasar tradisional tersebut yang juga menjual barang yang ada ditokonya secara onlinr namun sekalilagi perbedaan ada pada harga yang mereka patok dimana, harganya sama dengan harga toko mereka atau bisa saja harga yang telah dihitung dengan keuntungan yang mereka ambil tiap produknya.

Namun disisi lain ada juga konsumen atau pembeli yang tetap setiap membeli barang pada tokotoko yang ada dipasar tradisional tersebut, dimana mereka nyaman karena proses tawar menawar yang terjadi secara langsung antara penjual dan pembeli juga pelayanan ramah dan lainnya yang membuat kesan tersendiri pada setiap konsumen atau pembelinya, yang mana faktor ini menjadi pemikat kesetian setiap konsemen atau pembeli pada toko-toko yang ada dipasar tradisional tersebut.

Ada juga konsumen yang mengapa memilih toko-toko offline dipasar tradisional sebagai sarana mencari atau membeli barang dimana karena barang yang mereka inginkan di Marketplace atau Onlineshopnya memang lebih murah dibanding pada toko-toko ofline dipasar tradisionalnya, Namun biaya penanganan atau ongkos kirim yang menjadi masalahnya dimana ongkos kirim dipatok bisa cukup mahal tergantung jarak dari barang tersebut atau malah tergantung jasa ekspedisinya, yang mana jika di akumulasikan ongkos kirim yang cukup mahal dengan harga barangnya, bisa menjadi lebih mahal dibanding harga barang yang ada pada pasar tradisional, yang menjadikan konsumen lebih memilih datang langsung pada pasar tradisional karena mengapa tidak jika harganya lebih mahal daripada pasar tradisional, tentunya lebih baik memilih yang dimana barang tersebut bisa langsung kita jumpai atau kita lihat kualitasnya, supaya dapat kita nilai sendiri kualitas dan kuantitas dari barang tersebut. Dan tentunya dapat kita tawar secara langsung pada penjual tersebut, merupakan kemudahan bagi kita dan tentunya kita ridho dan penjual pun ridho dengan kesepakatan dari harga barang trsebut.

Namun juga tentunya untuk pasar tradisional yang menjual kebutuhan pangan seperti sayuran, buah-buahan, beras, daging dan ikan hingga saat ini masih sangat ramai kerena walaupun ada yang menjual kebutuhan pangasn secara online, pasar tradisional lebih dminati hingga saat ini karena untuk produk makanan tentunya butuh yang masih fress atau segar untuk kemudian dikonsumsi atau diolah, para konsumen pun tentunya lebih senang memilih milih dari setiap kebutuhan dari produk yang mereka cari masing-masing.

Karena memang untuk urusan pangan merupakan hal yang sensitif, segala hal yang terkait dengan pangan akan menarik perhatian konsumen atau pembeli yang harus sangat diperhatikan baik dari sisi

harga maupun keamanan pangannya, Walaupun Akad Al-Musawamah tersebut terjadi juga di pasar tradisional namun, menurut pengalaman bahwa harga yang diteteapkan atau dipatok oleh pedagang mengenai barang berupa pangan tersebut, cenderung harga yang sudah pas atau harga mati yang sudah dipatoknya tentu berdasarkan keuntungan yang didapatkannya, jangan cukup jarang proses tawar menawar atau Akad Al-Musawamah tersebut berbuah harga yang diinginkan konsumen atau pembelinya. 
Pada akhirnya kesepakatan final yang terjadi dimana harga masih tetap seperti awal ditawarkan oleh penjual pada konsumennya, Walaupun kadang harga yang disepakati bisa lebih murah dari harga awal yang dipatok, namun tentunya sangat jarang toko yang seperti itu, Krena cenderung keuntungan yang mereka ambil sangat sedikit tiap produknya.

Namun tentunya hal tersebut merupakan hal yang lumrah pada masyarakat dan tidak dipermasalahkan oleh seetiap konsumen atau pembelinya.Hal yang penting lagi yang kadang kala harus diperhatikan masyarakat dalam bertransaksi karena dizaman sekarang banyak orang yang mengetahui bahaya dari sebuah riba dan ada juga yang kurang tahu mengenai sebuah transaksi yang baik kadang kala ada masyarakat yang sangking berhati hati dalam bertransaksi mengira bahwa jika penjual menetapkan harga yang begitu tinggi pada sebuah barang atau produk dan mereka mengetahui harga pokok produk tersebut, mereka mengira atau bahkan mencap itu merupakan sebuah riba, tentunya semua ini akibat salah kaprah karena tentunya pengetahuan yang terbatas yang mereka miliki dan seharusnya sosialisasi pemerintah khususnya kementrian agama yang harus gencar mensosialisasikan dan memberi pemahaman pada masyarakat agar tidak ada salah kaprah atau kesimpulan yang jelas salah dari masyarakat

Itu pulalah dimana transaksi akad musawamah ini cukup berarti di masa kini karena si penjual tidak menyebutkan harga pokok dan keuntungan yang diambil pada setiap barang atau produk agar tentunya pemahaman-pemahaman yang salah atau kurang pasa masyarakat dapat diatasi secara tidak langsung.

\section{KEIMPULAN}

Dari yang telah dipaparkan diatas dapat disimpulkan bahwa pengimplementasian Akad AlMusawamah pada pada pasar tradisional, merupakan akad transaksi yang memang selalu terjadi di sana, dimana kedua belah pihak menyepakati dengan harga yang telah sebelumnya di sepakati bersama dengan cara proses tawar menawar antara kedua belah pihak dan kemudian keduannya saling ridho dan ikhlas, dan tentunya tidak boleh terjadi dusta diantaranya karena dapat menyebabkan rusaksnya transaksi tersebut dalam sisi zhohir maupun batin, namun juga tentunya transaksi ini dapat dijumpai pada toko-toko berupa pakaian atau benda benda mati lainnya. Karena patokan harga yang bercukup tinggi yang ditawarkan penjual, menyebabkan Akad transaksi Al-Musawamah ini terjadi atau proses tawar menawarnya supaya terjadi kesepakatan antara kedua belah pihak tersebut dan untuk hukumnya sah atau halal karena merupakan proses transaksi yang sangat biasa terjadi atau kita jumpai, bahkan kita lakukan saat ingin membeli sebuah barang, selagi tidak ada dusta atau kecurangan di dalamn transaksi tersebut.

\section{DAFTAR PUSTAKA}

\section{1. https://putusan3.mahkamahagung.go.id/peraturan/detail/ 11eb3f759876c5348a00313530363236.html}

\section{2. http://digilib.uinsby.ac.id/2166/8/Bab\%205.pdf}

\section{3. https://www.ekonomisyariah.org/4480/pasar-modal-syariah-dipastikan-halal/}

\section{4. https://www.cermati.com/artikel/tiru-cara-berdagang-ala-nabi-muhammad-insya-allah-laris- dan-barokah}

\section{5. https://www.republika.co.id/berita/q3c7og366/cara-berdagang-rasulullah}


6. https://penerbitbukudeepublish.com/pengertian-abstrak/

7. https://www.syariahpedia.com/2018/03/definisi-hukum-rukun-dan-syarat-akad.html

8. https://wartakota.tribunnews.com/2020/05/22/bolehkan-tawar-menawar-dalam-belanja-beginihukumnya-menurut-islam-dan-alquran?page=all

9. https://umma.id/post/tawar-menawar-yang-baik-menurut-islam-214933?lang=id

10. https://www.popbela.com/relationship/single/windari-subangkit/dalil-al-quran-dan-haditstentang-kejujuran-1/1

11. http://dkpp.jabarprov.go.id/post/48/Pengawasan-Pangan-Segar-dan-Dava-Tarik-Pasar

12. https://www.wartaekonomi.co.id/read283697/begini-tata-cara-tawar-menawar-menurutrasulullah-yuk-terapkan

13. https://tafsirweb.com/6143-surat-an-nur-ayat-15.html 